\title{
Price Discount Framing: How it Can Increase the Purchase Intention?
}

\author{
Gede Widiadnyana Pasek ${ }^{1 *}$, Ni Luh Sri Kasih ${ }^{2}$ \\ 1,2 College of Economics (STIE) Satya Dharma Singaraja, Indonesia
}

\section{A R T I C L E I N F O}

Article history:

Received 20 December 2020

Received in revised form

05 January 2021

Accepted 18 February 2021

Available online 25

February 2021

Keywords:

Price Discount Framing,

Purchase Intention, Gender

\begin{abstract}
A B S T R A C T
The high level of competition makes companies compete to retain and win the market competition, one of the strategies are granting price discounts. This was an experimental study that aims to analyze the differences between males and females' intention for online purchase by given the price discount framing conditions, namely percentage saving and absolute saving. The participants in this study were 80 participants. This study was an experimental study since it involved the symptoms had to be investigated. The design of the study was a $2 \mathrm{X} 2$ factorial design. A case questionnaire was used for the data collection. The data were analyzed by using 2-ways ANOVA statistical analysis. The study reveals that (1) there is a difference in online purchase intention between those given the percentage saving condition and those given the absolute saving condition, (2) there is a difference in purchase intention between males and females. The consumers have different assumptions about the two types of discount framing even though they both have the same meaning. This should be a concern for retailers in providing sales promotions, especially for discounts because based on the results of this study it is found that discount framing with absolute savings had a slightly stronger effect on purchase intention than percentage saving.
\end{abstract}

Copyright (C) Universitas Pendidikan Ganesha. All rights reserved.

\section{Introduction}

The development of the increasingly competitive business world requires every company to be more careful in determining marketing strategies to compete in the market. Various strategies have carried out by the company to increase sales and to attract as many consumers as possible (Griffin, 2005). As a result of the existing competition, various products have become increasingly diverse. Product is a key element in the market offering. The emergence of online trading will be a great opportunity for both companies and retailers to trade their products or services, but online trading will also be a challenge for companies that will demand new marketing strategies, therefore companies must review consumers and potential consumers who will do so. Buying and selling transactions via the internet by market segmentation (G. Choi et al., 2020; Crespo \& Bosque, 2008).

Market leaders typically offer high quality products and services that provide the most superior customer value. Companies are expected to have a strong competitive advantage in order to survive in the business competition (Curtis et al., 2011). There are three generic strategies that companies from various industries can be chosen to gain a competitive advantage for their business. Those are cost leadership, differentiation, and focus. The cost leadership strategy is used by the companies to achieve the lowest costs compared with other companies in one industry. Then, the differentiation strategy is used by companies to be unique in certain dimensions of the products that they produce. Meanwhile, the focus strategy is divided into two types of strategies, namely companies that have a strategic focus on differentiation focus and cost focus. Companies that focus on differentiation will try to reach customers who are not well served by other companies by offering products or services that are different from competitors. Meanwhile, companies that focus on costs will try to reach customers who have a need for products at lower prices in an industry that cannot be served well by other companies that have a wider market scope (D. Solihin, 2020; I. Solihin, 2012). 
A price is the only element of the marketing mix that generates sales revenue for the company (Assauri, 2008). A price has many forms and carries out many functions (Faryabi et al., 2012; Kotler \& Keller, 2012). Throughout history, prices are agreed through negotiations between buyers and sellers. Fixing one price for all buyers is a relatively modern idea that arose with the development of large-scale retail trade in the late nineteenth century. In general, consumers tend to like products at lower prices. Some companies experiencing a state of overcapacity have tempted to give discounts, even starting to supply retailers with store brand versions of their products at deep discounts (Kotler \& Keller, 2012). Retailers should ensure that words such as "sale" or "special" are used on discounts, then that consumers believe that the discount or rebate is only for a temporary period and does not perceive it as an excuse for poor product quality (Faryabi et al., 2012). Many companies offer quantity discounts for buying in bulk and seasonal discounts for seasonal purchases (Wood, 2009). Business customers can also get cash discounts to speed up payments and intermediaries can get discounts when performing special channel functions for producers. This makes companies often use sales promotions by providing massive discounts or discounts on their products in order to attract consumer purchase intentions.

Rebates can be physically marked on the product. Retailers do labelling prices that are lower than before. Discount sales promotions have proven to be more successful than other sales promotions for two reasons. Firstly, discounting has the appeal of monetary savings and secondly, the benefits can be enjoyed directly, unlike the rebates, refunds, sweepstakes and others (Clow \& Baack, 2014). Discounted sales promotion techniques typically used by retailers at the point of purchase that allow the customers to compare the selling price with multiple (higher) reference prices and in principle allow retailers to show customers that a particular purchase offers superior value as a consequence of a reduced price. However, the approach is generally seen as a means of increasing consumer perceptions of value and increasing the likelihood of purchase (McKechnie et al., 2012). One of the ways consumers are influenced in purchasing decisions is through price framing, in other words, price promotional messages are framed in an offer (Carlos Alberto et al., 2020; McKechnie et al., 2012).

Framing is a phenomenon that indicates decision makers will respond in different ways to the same problem if presented in different formats. The framing of information can influence a person's decision making. Framing is closely related to reference points. In framing, this reference point becomes a frame for a person to consider possibilities. Price discounts are presented in two types, namely, absolute saving and percentage saving. Framing a discount by writing an absolute nominal is also called absolute saving (Faryabi et al., 2012; Saputri et al., 2018). Meanwhile, framing a discount in the form of a percentage is also called a percentage saving. Alternative words can be seen and assumed differently even though they represent the same savings. The consumer can be informed of a 50 percent discount or $1 / 2$ the bid price, while a rational consumer should treat these two offers the same. Price discounts will be more effective if it is presented in dollars and cents or writing nominal (absolute savings) for high-priced products and in percentage (percentage saving) for the low-price products. Prices tend to be evaluated by consumers in relative terms (percentage saving) rather than absolute nominal (absolute saving or nominal). However, when drawing a difference between a high-price product and a low-price product, Price discount should be presented in dollars (i.e. Absolute or nominal). The first study to find empirical support used an experimental design that involved one product in each class (i.e. computers for high-price products and floppy disks for low-price products). Although they found significant differences in respondents' perceptual responses to current offers for discounts framed numerically in dollar amounts and percentages, and no significant differences were found in their behavioral responses, which were associated with attitude gaps and product-specific factors such as falling market prices. Moreover, shorter product life cycles for technology products such as computers (McKechnie et al., 2012).

Discount prices should be framed in absolute terms (dollars) for high-price products (in this case stereo and computers), but framing has little or no effect on low-price products (in these case chips potato and cola) (Gendall et al., 2006). Even discount framing had no effect for cola but it was slightly more effective for potato chips when expressed as a percentage, although no significant difference was found in consumer responses. Meanwhile, the effect of framing discounts on promotions is influenced by the size of the discount in the low-product context, not on high-products (McKechnie et al., 2012). Marketers already understand that gender, money, and spending now seem to have become an inseparable unit.

Some researches in marketing also include demographic variables in their analysis. Among the most studied demographic variables is gender. The influence of gender will depend on various factors. For example, in terms of product choice, female consumers pay more attention to various products related to house furnishings than male consumers do. Gender refers to everything related to an individual's gender, including roles, behavior, tendencies, and other attributes that define the meaning of being a man or woman in an existing culture (Baron \& Byrne, 2003). Marketers need to market their products through gender-based market segmentation that will provide benefits and opportunities for businesses (Sortino \& 
Price, 1994). Male and female have their own patterns when spending money on certain products. Gender is part of market segmentation in terms of demographics, which is considered by producers in marketing products. Gender is a trait inherent in both men and women who are constructed socially and culturally (Fakih, 2008). Women use the internet to give and receive social support. They use e-commerce transactions in a more emotional way (Garbarino \& Strahilevitz, 2004). According to (Rodgers \& Harris, 2003) men are more likely to buy products and services online, and also their attitudes towards online shopping are more positive than women. It is found that men have a tendency to believe and be satisfied with the consequences of online shopping, and as the result, they take more advantage of shopping online (Slyke et al., 2002).

A study that reveals a relationship between consumer intention and behaviour (L. Choi et al., 2019). Furthermore, the relationship is based on the fact that humans always try to make rational decisions based on the information available to them. Thus, a person's intention to take or not take action is a direct determinant of the real action that a person takes. Based on the relationship between interest and action above, (Kim et al., 2008) emphasize that interest in taking action, or more specific interest in making a purchase, is an estimate of the real action or purchase decision made by consumers. (Meldarianda et al., 2010) conclude that what is meant by consumer buying interest is a process of planning the purchase of a product that will be carried out by consumers by considering several things, including the number of product units needed in a certain period of time, brands and consumer attitudes in consuming. Meanwhile, (Nugraha, 2013) explains that buying interest is obtained from a learning process and a thought process that forms a perception. The interest that arises in making a purchase creates a motivation that continues to be recorded in the consumer mind and becomes a very strong activity that in the end when a consumer has to fulfill the needs will be actualized what is in his or her mind.

Purchase intention is an impulse that arises in a person to buy goods or services in order to fulfill his or her needs (McCarthy \& William, 2002). Purchase intention is a process for analyzing and predicting consumers' behavior in relation to their willingness to buy, use, and pay attention to certain brands (Imari et al., 2008). Intention as a behavioral tendency, which a person does if there are the right time and opportunity and will be shown in the form of action. Most companies will adjust their price lists and provide discounts and discounts (discounts and allowances) for faster payments, bulk purchases, and outof-season purchases. Companies must do this carefully if they do not want their profits far decrease as what as planned (Kotler \& Keller, 2012). This study aims to analyze the differences between males and females' intention for online purchase by given the price discount framing cnditions, namely percentage saving and absolute saving.

\section{Methods}

This study was an experimental study since it involved the symptoms had to be investigated, treatment must be given, which was something that might be the cause. The experimental design was post test only control group design. The design of the study was a $2 \times 2$ factorial design. There were two variables in this study. The first independent variable was the price discount framing which consists of the percentage saving and absolute saving charged to the experimental group and to the control group. The second variable was gender. The genders are divided into two, namely male and female. In this study, the total participants were 80 .

The researchers provided some stages in conducting the research. In the first stage, the respondents were given a questionnaire in the form of a case. Then they were given time to read the case, the researchers instruct that the respondents experience an incident that occurs in the case. After reading the case given, the respondents were asked to fill in the considerations in the case. After then the respondents put the questionnaire into the envelope provided. In the second stage, the researchers gave some questions to the respondents to make sure that they really understand the case given.

This study used a $2 \times 2$ factorial design, which means that this experiment used two levels of conditions by obtaining a percentage saving condition and obtaining an absolute saving condition as well as two levels for male and female categories. The factorial design was used to test the effect of price discount framing which consists of percentages of saving, absolute saving and gender on the intention to buy goods online. The researchers observed the tendency of people to buy goods online by providing cases. After the cases in the experiment were completed, participants were presented with the questions. The participants were asked to give true or false statements based on the questions. The questioning was done to find out the participants' understanding of the manipulations given. If the participants were successful in answering the questions, then the researchers analyzed the data. The participants were divided into several groups: (1) group 1: the females group with the saving percentage conditioning 
treatment, (2) group 2: the males group with the saving percentage conditioning treatment (3) group 3 : the females group with absolute saving conditioning treatment and (4) group 4: males group with absolute saving conditioning treatment. The data testing conducted in this study includes the frequency distribution for descriptive statistics. In order to test the hypothesis in this study, the Two-Way Analysis of Variance statistical test was used. This study used Two-Way Anova because this research used two independent variables, namely price discount framing which consists of percentage saving and absolute saving and gender variable and one dependent variable, namely purchase intention.

\section{Results and Discussions}

\section{Results}

The data obtained in the study are gender, which is classified into categories, namely women and men, and online purchase intention behavior which is given the percentage saving and absolute saving treatments. The data details of gender and purchase intention are shown in Table 1.

Table 1. Description of data

\begin{tabular}{llcc}
\hline \multicolumn{1}{c}{ Gender } & \multicolumn{1}{c}{ Treatment } & Group & Mean \\
\hline Female & Percentage Saving & 1 & 2.8 \\
& Absolute saving & 3 & 3.1 \\
Male & Percentage Saving & 2 & 4.1 \\
& Absolute saving & 4 & 5.6 \\
\hline
\end{tabular}

From Table 1, it shows that the participants in group 1, with total data, are 20 females who received the Percentage of Saving treatment has an average value of 2.8. Then, in group 2, with the total data are 20 male and get the percentage of saving has an average value of 4.1 . While in group 3 , with 20 females getting Absolute saving treatment has an average value of 3.1. Then, in group 4, the total data of 20 males getting Absolute saving treatment has an average value of 5.6. To test the research hypotheses, Two-Way Analysis of Variance (ANOVA) was used. Hypothesis testing is carried out at a significance limit of $5 \%$. To find out the significance of the test results, researchers only need to look at the p-value generated from processing the data.

Testing the first hypothesis is to examine whether there is a difference in online purchase intention between subjects who get a percentage saving and subjects who get absolute saving. In Table 2, the results of Tests of Between-Subjects Effects are presented to compare between groups / treatments. The results of the analysis in Table 2 show that the Sig coefficient value is $0.001(<0.05)$ so that $\mathrm{H}_{1}$ which states that there is a difference in online purchase intention between subjects who get a percentage saving and subjects who get absolute saving is accepted. Thus, it can be stated that there is a difference in online purchase intention between subjects who get a percentage saving and subjects who get absolute saving.

While $\mathrm{H}_{2}$ hypothesis testing is conducted to determine whether there is a difference between males and females on purchase intention. In Table 2, the results of Tests of Between-Subjects Effects are presented to compare between groups / treatments. The results of the analysis in Table 2 show that the Sig coefficient value of 0.000 is smaller than the specified alpha (5\%). Thus, it can be concluded that $\mathrm{H}_{2}$ that states there is a difference in purchase intention between male and female subjects is accepted. The results of the calculation using the two-way ANOVA can be seen in Table 2 as follows.

Table 2. Tests of Between-Subjects Effects

\begin{tabular}{ccc}
\hline Variable & F & Sig. \\
\hline Price discount & 11.442 & .001 \\
Gender & 50.996 & .000 \\
\hline
\end{tabular}

\section{Discussions}

The $\mathrm{H}_{1}$ test was conducted to examine the differences between subjects who were given a saving percentage and subjects who were given absolute saving. The results show that the Sig coefficient value for the first Hypothesis is accepted with a Sig coefficient value of 0.001 below 0.05 . Thus, it can be stated that there is a difference in online purchase intention between subjects in a condition where there is absolute saving treatment and there is a percentage saving treatment. The results of this study support the research of (Gendall et al., 2006) that price discounts framed in absolute terms are more influential than the percentage of saving. Table 1 shows that the mean purchase intention of the group where the 
average online purchase intention of the male is greater than the female. This shows that women tend to be careful in making risky decisions, as online purchase intention compared to men. Then Table 1 shows that group 1 with female based whose percentage of saving has a mean of 2.8 which is lower than group 2 with male based, the percentage of saving has a mean of 4.1. Then the Table 1 also shows that group 3 with female based gets absolute saving treatment has a mean that is 3.1 , which is lower than group 4 with the male based who gets absolute saving has a mean of 5.6. This shows that the individual who gets the percentage of saving influence is smaller in purchase intention than the individual who gets absolute saving. Table 2 also shows that the mean difference is significant with a p-value less than 0.05 . Based on the results of the hypothesis testing, the price discount framing gives a difference to online purchase intention, by being given a discount price framing treatment on purchase intention, it will have an impact on individuals to purchase intention online. The results of $\mathrm{H}_{2}$ testing indicate the differences between subjects with males and females. The results show that the Sig coefficient value for Hypothesis 2 is accepted with a Sig coefficient value of 0.000 below 0.05 , so it can be stated that there is a difference in purchase intention behavior between males and females. Table 1 shows that male groups on group 2 and group 4 have a mean of 4.1 and 5.6 which are higher than female groups on group 1 and group 3 with a mean of 2.8 and 3.1 This means that females tend to do not make purchase intention online compared to males. The results of this study support the study of (Rodgers \& Harris, 2003) that men are more likely to buy products and services online, and also their attitudes towards online shopping are more positive than women. It is found that men have a tendency to believe and be satisfied with the consequences of online shopping, and as a result, they take more advantage of shopping online (Slyke et al., 2002).

Framing is a phenomenon that indicates decision makers will respond in different ways to the same problem if presented in different formats. The framing of information can influence a person's decision making. Framing is closely related to reference points. In framing, this reference point becomes a frame for a person to consider possibilities. Price discounts are presented in two types, namely, absolute saving and percentage saving. Framing a discount by writing an absolute nominal is also called absolute saving (Faryabi et al., 2012; Saputri et al., 2018). Meanwhile, framing a discount in the form of a percentage is also called a percentage saving. Alternative words can be seen and assumed differently even though they represent the same savings. The consumer can be informed of a 50 percent discount or $1 / 2$ the bid price, while a rational consumer should treat these two offers the same. Price discounts will be more effective if it is presented in dollars and cents or writing nominal (absolute savings) for high-priced products and in percentage (percentage saving) for the low-price products. Prices tend to be evaluated by consumers in relative terms (percentage saving) rather than absolute nominal (absolute saving or nominal). However, when drawing a difference between a high-price product and a low-price product, Price discount should be presented in dollars (i.e. Absolute or nominal). The first study to find empirical support used an experimental design that involved one product in each class (i.e. computers for high-price products and floppy disks for low-price products). Although they found significant differences in respondents' perceptual responses to current offers for discounts framed numerically in dollar amounts and percentages, and no significant differences were found in their behavioral responses, which were associated with attitude gaps and product-specific factors such as falling market prices. Moreover, shorter product life cycles for technology products such as computers (McKechnie et al., 2012).

Discount prices should be framed in absolute terms (dollars) for high-price products (in this case stereo and computers), but framing has little or no effect on low-price products (in these case chips potato and cola) (Gendall et al., 2006). Even discount framing had no effect for cola but it was slightly more effective for potato chips when expressed as a percentage, although no significant difference was found in consumer responses. Meanwhile, the effect of framing discounts on promotions is influenced by the size of the discount in the low-product context, not on high-products (McKechnie et al., 2012). Marketers already understand that gender, money, and spending now seem to have become an inseparable unit.

Some researches in marketing also include demographic variables in their analysis. Among the most studied demographic variables is gender. The influence of gender will depend on various factors. For example, in terms of product choice, female consumers pay more attention to various products related to house furnishings than male consumers do. Gender refers to everything related to an individual's gender, including roles, behavior, tendencies, and other attributes that define the meaning of being a man or woman in an existing culture (Baron \& Byrne, 2003). Marketers need to market their products through gender-based market segmentation that will provide benefits and opportunities for businesses (Sortino \& Price, 1994). Male and female have their own patterns when spending money on certain products. Gender is part of market segmentation in terms of demographics, which is considered by producers in marketing products. Gender is a trait inherent in both men and women who are constructed socially and culturally (Fakih, 2008). Women use the internet to give and receive social support. They use e-commerce transactions in a more emotional way (Garbarino \& Strahilevitz, 2004). According to (Rodgers \& Harris, 
2003) men are more likely to buy products and services online, and also their attitudes towards online shopping are more positive than women. It is found that men have a tendency to believe and be satisfied with the consequences of online shopping, and as the result, they take more advantage of shopping online (Slyke et al., 2002).

A study that reveals a relationship between consumer intention and behaviour (L. Choi et al., 2019). Furthermore, the relationship is based on the fact that humans always try to make rational decisions based on the information available to them. Thus, a person's intention to take or not take action is a direct determinant of the real action that a person takes. Based on the relationship between interest and action above, (Kim et al., 2008) emphasize that interest in taking action, or more specific interest in making a purchase, is an estimate of the real action or purchase decision made by consumers. (Meldarianda et al., 2010) conclude that what is meant by consumer buying interest is a process of planning the purchase of a product that will be carried out by consumers by considering several things, including the number of product units needed in a certain period of time, brands and consumer attitudes in consuming. Meanwhile, (Nugraha, 2013) explains that buying interest is obtained from a learning process and a thought process that forms a perception. The interest that arises in making a purchase creates a motivation that continues to be recorded in the consumer mind and becomes a very strong activity that in the end when a consumer has to fulfill the needs will be actualized what is in his or her mind.

Purchase intention is an impulse that arises in a person to buy goods or services in order to fulfil his or her needs (McCarthy \& William, 2002). Purchase intention is a process for analyzing and predicting consumers' behavior in relation to their willingness to buy, use, and pay attention to certain brands (Imari et al., 2008). Intention as a behavioral tendency, which a person does if there are the right time and opportunity and will be shown in the form of action. Most companies will adjust their price lists and provide discounts and discounts (discounts and allowances) for faster payments, bulk purchases, and outof-season purchases. Companies must do this carefully if they do not want their profits far decrease as what as planned (Kotler \& Keller, 2012).

\section{Conclusion}

This study aimed to examine the price of discount framing on online purchase intention behavior by considering gender factors. Therefore, the test is done by using ANOVA. Based on the research results and discussions of price framing discounts on purchase intention with gender based, the researchers fall to the following conclusions (1) price discount framing has an effect on online purchase intention behavior, so there are differences in purchase intention behavior between those given the percentage saving treatment and absolute saving, Price discount framing is a way for companies to convey price promotion messages to attract consumer purchase intentions. There are two types of price discount framing, namely percentage saving by showing the percentage of the discount given and also absolute savings, namely framing discounts by writing the nominal value of the price after the discount. Consumers are more interested in buying goods with the initial price that has been crossed out and replaced with a lower price (2) Gender has an effect on online purchase intention behavior. Thus, there are differences in online purchase intention behavior between males and females. Surprisingly, when looking at the average value of the two types of price discount framing, absolute saving has a slightly bigger effect than percentage saving. The consumers have different assumptions about the two types of discount framing even though they both have the same meaning. This should be a concern for retailers in providing sales promotions, especially for discounts because based on the results of this study it is found that discount framing with absolute savings had a slightly stronger effect on purchase intention than percentage saving.

\section{References}

Assauri, S. (2008). Manajeman Produksi dan Operasi. Fakultas Ekonomi Universitas Indonesia.

Baron, R. A., \& Byrne, D. (2003). Psikologi Sosial. Erlangga.

Carlos Alberto, G., Myriam, M.-F., I.Viedma-del-Jesús, M., \& Aranda, L. A. (2020). The processing of price during purchase decision making: Are there neural differences among prosocial and nonprosocial consumers? Journal of Cleaner Production, 271, 26-48. https://doi.org/https://doi.org/10.1016/j.jclepro.2020.122648.

Choi, G., Kim, J., Sawitri, M. Y., \& Lee, S. K. (2020). Ecotourism market segmentation in Bali, Indonesia: Opportunities for implementing REDD+. Land, 9(6), 1-15. https://doi.org/10.3390/LAND9060186.

Choi, L., Lawry, C. A., \& Kim, M. (2019). Contextualizing customer organizational citizenship behaviors: 
The changing nature of value cocreation and customer satisfaction across service settings. Psychology \& Marketing, 36, 455-472. https://doi.org/10.1002/mar.21190.

Clow, K. E., \& Baack, D. (2014). Integrated Advertising, Promotion, and Marketing Communications. Pearson Education Limited.

Crespo, A. H., \& Bosque, I. R. (2008). The Effect Of Innovativeness On The Adoption Of B2C E-Commerce : A Model Based On The Theory Of Planned Behavior. Computer In Human Behavior Journal, 28302847. https://doi.org/10.1016/j.chb.2008.04.008.

Curtis, T., Abratt, R., \& Rhoades, D. L. (2011). Customer Loyalty, Repurchase and Satisfaction: A MetaAnalytical Review. Journal of Consumer Satisfaction, Dissatisfaction and Complaining Behavior, 24(1), 1-26. https://commons.erau.edu/db-management/18/.

Fakih, M. (2008). Analisis Gender dan Transformasi Sosial. Insistpress.

Faryabi, M., Sadeghzadeh, K., \& M Saed. (2012). he Effect of Price Discounts and Store Image on Consumer's Purchase Intention in Online Shopping Context Case Study: Nokia and HTC. Journal of Business Studies Quarterly, 4(1), 197-205. https://doi.org/10.1.1.653.5017.

Garbarino, E., \& Strahilevitz, M. (2004). Gender differences in the perceived risk of buying online and the effects of receiving a site recommendation. Journal of Business Research, 768-775. https://doi.org/10.1016/S0148-2963(02)00363-6.

Gendall, P., Hoek, J., Pope, T. a, \& Young, K. (2006). Message Framing Effects on Price Discounting. Journal of Product \& Brand Management, 15(7), 458. https://doi.org/10.1108/10610420610712847.

Griffin, J. (2005). Customer Loyalty: Menumbuhkan dan Mempertahankan Kesetiaan Pelanggan. Erlangga.

Imari, S., Permana, honeyta lubis., \& Syafrudin, C. (2008). Pengaruh Orientasi Belanja, Kepercayaan Online Dan Pengalaman Pembelian Sebelumnya Terhadap Niat Pembelian Konsumen Secara Online Dengan Perbedaan Gender Sebagai Variabel Pemoderasi. Jurnal Perspektif Manajemen Dan Perbankan, 8(3), 49-70. http://www.jurnal.unsyiah.ac.id/JPMP/article/view/10189.

Kim, D. J., Ferrin, D. L., \& Rao, H. R. (2008). A trust-based consumer decision-making model in electronic commerce: The role of trust, perceived risk, and their antecedents. Decision Support Systems, 44(2), 544-564. https://doi.org/10.1016/j.dss.2007.07.001.

Kotler, \& Keller. (2012). Manajemen Pemasaran (12th ed.). Erlangga.

McCarthy, E. J., \& William, D. P. (2002). Dasar-Dasar Pemasaran (5th ed.). Erlangga.

McKechnie, S., James., D., Ennew, C., \& Smith, A. (2012). ffects of Discount Framing in Comparative Price Advertising. European Journal of Marketing, 46(11/12), 1501-1522. https://doi.org/10.1108/03090561211259952.

Meldarianda, R., Lisan, H., \& Kristen, U. (2010). Pengaruh store atmosphere terhadap minat beli konsumen pada resort café atmosphere Bandung. Jurnal Bisnis Dan Ekonomi (JBE), 17(2), 97-108. https://www.unisbank.ac.id/ojs/index.php/fe3/article/view/329/213.

Nugraha, B. A. (2013). Persepsi Terhadap Store Atmosphere Dengan Minat Beli Konsumen Di Hypermarket. Cognicia: Jurnal Online Psikologi, 1(2), 515-528. https://doi.org/10.22219/COGNICIA.Vol1.No2.\%25p.

Rodgers, S., \& Harris, M. A. (2003). Gender and e-commerce: an exploratory study. Journal of Advertising Research, 43(3), 322-329. https://doi.org/10.2501/JAR-43-3-322-329.

Saputri, S. A., Mardani, R. M., \& Wahono, B. (2018). Pengaruh Price Book Value (PBV), Price Earning Ratio (PER), Return On Assets (ROA) Terhadap Return Saham. Jurnal Riset Manajemen, 133-149.

Slyke, C. V., Comunale, C. L., \& Belanger, F. (2002). Gender differences in perceptions of web-based shopping. Communication of the ACM, 45(8), 82-86. https://doi.org/10.1145/545151.545155.

Solihin, D. (2020). Pengaruh Kepercayaan Pelanggan Dan Promosi Terhadap Keputusan Pembelian Konsumen Pada Online Shop Mikaylaku Dengan Minat Beli Sebagai Variabel Intervening. Jurnal MANDIRI: Ilmu Pengetahuan, Seni, Dan Teknologi, 4(1), 38-51. https://doi.org/10.33753/mandiri.v4i1.99.

Solihin, I. (2012). Manajeman Strategik. Erlangga.

Sortino, F. A., \& Price, L. N. (1994). Performance Measurement in a Downside Risk Framework. The Journal of Investing. https://doi.org/10.3905/joi.3.3.59.

Wood, M. B. (2009). Perencanaan Pemasaran (B. Monel (ed.); 3rd ed.). PT Indeks. 